\title{
Excluding Nontarget Species from Brown Tree Snake, Boiga irregularis (Reptilia: Colubridae), Bait Stations: Experimental Tests of Station Design and Placement ${ }^{1}$
}

\author{
Tom Mathies, ${ }^{2,5}$ Russell Scarpino, ${ }^{2,3}$ Brenna A. Levine, ${ }^{2,3}$ Craig Clark, ${ }^{4}$ and Fulie A. Savidge ${ }^{3}$
}

\begin{abstract}
Bait stations with toxic baits are an emerging technology for eradication of the invasive brown tree snake (Boiga irregularis) on Guam, yet potential interferences by nontarget species are largely unknown. We tested the efficacies of three bait station designs together with three commonly used station support structures to exclude nonnative rats (roof rat, Rattus rattus; Norway rat, Rattus norvegicus; Polynesian rat, Rattus exulans) and native coconut crabs (Birgus latro). When directly presented, all species readily consumed the dead neonatal mouse baits (nontoxic) including those replicating decomposing baits in the field. When bait stations were made easily accessible by placement near ground level, all rat species were able to enter all station types, but some individual roof rats and Norway rats exhibited apparent neophobia. When stations were placed up on support structures, simulating those in the field ( $\sim 1 \mathrm{~m}$ above ground level), numbers of station accessions by roof rats and Norway rats remained essentially unchanged, but Polynesian rats then showed almost no inclination to enter stations. However, ability to access entrances of stations (but not interiors) when on support structures was extremely high for roof rats and appreciable for the other rat species, including Polynesians. The station type currently in widest use, when placed on chain-link cyclone fence, had the highest probability of accession. Crabs readily accessed station entrances but never interiors. The two downward-angled station designs, when placed in simulated vegetation, had the lowest probabilities of accession. In areas where nontarget species are a concern, we recommend use of either of the downward-angled station designs and suspension from vegetation wherever possible.
\end{abstract}

\footnotetext{
${ }^{1}$ Funding for this research was provided by U.S. Navy, Naval Facilities Engineering Command Marianas. Work was conducted under two study protocols: NWRC QA-1466 and Colorado State University 07-234A-01 approved by NWRC and Colorado State University Animal Care and Use Committees, respectively. Manuscript accepted 12 April 2010.

2 U.S. Department of Agriculture, Animal Plant Health Inspection Service, Wildlife Services, National Wildlife Research Center, 4101 LaPorte Avenue, Fort Collins, Colorado 80521-2154.

${ }^{3}$ Department of Fish, Wildlife, and Conservation Biology, Colorado State University, Fort Collins, Colorado 80523-1474.

${ }^{4}$ U.S. Department of Agriculture, Animal Plant Health Inspection Service, Wildlife Services, 233 Pangelinan Way, Barrigada, Guam 96913.

${ }^{5}$ Corresponding author (phone: 970-226-6324; e-mail: tom.c.mathies@usda.gov).
}

Pacific Science (2011), vol. 65, no. 1:41-57

doi: 10.2984/65.1.041

(C) 2011 by University of Hawai'i Press

All rights reserved
Since the realization nearly 25 years ago that the introduced brown tree snake, Boiga irregularis (Merrem), had decimated nearly all of Guam's native vertebrate species (Marshall 1985, Savidge 1986, 1987), a diversity of control methods has been investigated. The most successful of these methods are being used and refined in an integrated pest management approach (Engeman and Vice 2001) with the goals of preventing transport of snakes from Guam to other at-risk areas, detecting and eradicating potential incipient populations, and severely suppressing population levels on Guam (Colvin et al. 2005). Severe population suppression has an overarching importance because, when effectively implemented and sustained, it may be possible to reduce the scope and intensity of other containment efforts and attendant costs.

No large-scale reductions have yet been conducted, but much of the basic technology 
and methodology have been developed. The basis of the most promising technology is an acetaminophen-containing dead neonatal mouse (DNM) bait that is toxic to snakes when ingested (Brooks et al. 1998, Savarie et al. 2000). There are two main methodologies for deploying DNM baits on Guam: aerial delivery by fixed-wing aircraft or helicopter, generally in areas that are difficult to access by other means; and manual placement inside open-ended PVC bait stations arrayed within and/or around prescribed areas, generally where aerial application is not desirable, such as ports. Aerial application on an operational level, though close to realization, has not yet been implemented. Operational use of bait stations, however, has begun (e.g., Orote Peninsula [D. Vice, pers. comm.]), and a number of issues requiring evaluation have subsequently come to light. One issue is nontarget animal interference and how best to limit their take of bait. Limiting take by nontargets is essential on Guam for many of the same reasons as elsewhere; potential bait take by the federally endangered Mariana Crow was mitigated using a surrogate crow species to show that a minor modification in bait station design (entrance diameter reduction) was sufficient to prohibit access by crows (Avery and Tillman 2001). There is anecdotal evidence that the coconut crab, Birgus latro (L.), takes bait from bait stations (C.C., unpubl. data), and this species is consumed locally, playing an integral part in Chamorro culture. From an operational standpoint, the most critical reason for limiting nontarget bait take is that baits taken by nontargets are thus unavailable to brown tree snakes, and take is the proxy for the number of snakes removed from an area. The necessity of obtaining confident estimates of numbers of snakes removed creates concern when other nonnative invasives, particularly Rattus spp., may be removing baits. At least three rat species have been documented on Guam: the roof rat, Rattus rattus (L.); Norway rat, Rattus norvegicus (Berkenhout); and Polynesian rat, Rattus exulans (Peale) (Baker 1946, Crabb and Emik 1946, Barbehenn 1974, Savidge 1987), although good estimates of current density are available only for $R$. rattus (Rattus diardii
[Wiewel et al. 2009]; taxonomy sensu Robins et al. [2007]). No information is available on propensities of these species to take DNM baits.

Because the brown tree snake is primarily arboreal, bait stations are placed $\sim 1.3 \mathrm{~m}$ above the ground, not only to facilitate access by snakes but also to limit access by terrestrial nontarget species. A number of bait station designs have been used operationally, but their efficacies for excluding nontargets have not been systematically investigated. A complicating factor is that heterogeneity within the structural environment where stations are deployed often necessitates placing stations in places that may affect station accessibility (e.g., stations are generally hung in vegetation but are hung from tripods where vegetation is absent). Our study evaluated accessibility of three station designs used operationally in the three most common placement situations to four putative nontarget species: $R$. rattus, $R$. norvegicus, $R$. exulans, and the coconut crab, B. latro.

\section{MATERIALS AND METHODS}

\section{Animals}

Roof rats ( $R$. rattus: seven males, 11 females) were collected from an established population in Phoenix, Arizona, and were transported by vehicle to the animal care facility at the U.S. Department of Agriculture National Wildlife Research Center (NWRC) in Fort Collins, Colorado, on 24-25 July 2007. Norway rats ( $R$. norvegicus: 12 males, eight females) were collected from a dairy farm in Weld County, Colorado, and transported by vehicle to NWRC on 19-20 September 2007. Polynesian rats ( $R$. exulans: four males, six females) were collected in a rural area on the island of Hawai'i and shipped via airfreight to NWRC on 29-30 July 2007. Rats were individually housed in cages and provided enough rodent chow (LabDiet Formulab 5008, PMI Nutrition, Henderson, Colorado) to maintain body weights within $7 \%$ of their weight upon arrival. We provided drinking water ad libitum. Body masses of roof rats, Norway rats, and Polynesian rats ranged from 71.5 to 
$192.5 \mathrm{~g}($ mean $=181.1 \mathrm{~g}, \mathrm{SD}=27.5), 230.0$ to $370.0 \mathrm{~g}$ (mean $=343.9 \mathrm{~g}, \mathrm{SD}=79.9)$, and 40.2 to $78.8 \mathrm{~g}$ (mean $=71.0 \mathrm{~g}, \mathrm{SD}=16.9)$, respectively. We housed all rats in the same room at $\sim 22^{\circ} \mathrm{C}$, with a photoperiod of $12 \mathrm{hr}$ light: $12 \mathrm{hr}$ dark.

Coconut crabs (B. latro: 11 males, 16 females) were collected from U.S. Navy land on Guam and shipped via airfreight to NWRC on 9-10 September 2007. We maintained crabs in a room at $25-26^{\circ} \mathrm{C}$ at $85 \%$ relative humidity under a $12 \mathrm{hr}$ light: $12 \mathrm{hr}$ dark photoperiod. They were housed individually in smooth steep-sided plastic bins containing pea-gravel substrate and a PVC pipe hide. We provided each individual with an omnivore diet (Mazuri Omnivore-Zoo Feed A, PMI Nutrition, Henderson, Colorado) and chunks of fresh coconut. Cuttlefish bone (for calcium supplementation) and drinking water were provided ad libitum. Body masses of crabs ranged from 93.4 to $521.3 \mathrm{~g}$ $($ mean $=208.5 \mathrm{~g}, \mathrm{SD}=107.4)$, and carapace widths ranged from 44.9 to $86.0 \mathrm{~mm}$ $($ mean $=59.0 \mathrm{~mm}, \mathrm{SD}=11.4)$.

\section{Experiment 1: Acceptance of DNM as Bait}

This experiment identified those species that did not readily consume DNM so that they could be excluded from any further experiments. We assumed that any species that did not consume DNM, when provided easy access, would not consume appreciable numbers of DNM in the field, at least not when their usual foods are available. Operationally, DNM baits are placed in the field and replaced every 2 to 3 days. Thus, a DNM may remain in the field up to 3 days if not consumed. By the second day in the field DNM are generally putrid. We simulated the varying conditions of bait in the field by assigning each DNM to one of two treatments: freshly thawed ("Fresh DNM" hereafter) or aged ("Aged DNM" hereafter). We aged DNM by placing them on a tray in a room at 25$26^{\circ} \mathrm{C}$ at $85 \%$ relative humidity for $24 \mathrm{hr}$. The DNM in this and other experiments herein were purchased frozen from Rodentpro (Inglefield, Indiana). Each animal was tested in its maintenance cage on two consec- utive days ("Day 1" and "Day 2" hereafter), receiving one DNM on each day. We used a counterbalance design where animals were randomly assigned to treatments within species such that on Day 1 approximately half the individuals of a species received Fresh DNM and the other half received Aged DNM; on Day 2, individuals that received Fresh DNM on Day 1 received Aged DNM and vice versa. At the beginning of a test, we placed one DNM in the overhead food bin of each rat cage and in a ceramic cup placed on the floor of each crab cage. Each rat and crab also received its regular allotment of rodent chow on both test days. Chow consumption was not monitored. We provided water ad libitum to all animals. We weighed each DNM to the nearest $0.1 \mathrm{~g}$ just before placing in a cage in the late afternoon. We checked bait consumption the following mornings and reweighed any remaining DNM. We corrected masses of remaining baits for changes unrelated to consumption (e.g., evaporation) using change in mass of uneaten baits. This experiment was initiated on 6 February 2008.

\section{Experiment 2: Identification of Preferred Baits}

The objective of this experiment was to identify a preferred bait(s) for each species, which were then used in Experiment 3 (see description following). In late afternoon, we presented each rat with a preweighed portion of DNM (DNM cut in half: mean $=4.9 \mathrm{~g}$; $\mathrm{SD}=0.5$; observations by species during Experiment 1 revealed no obvious preferences for either anterior or posterior ends of DNM), peanut butter-rolled oat mixture $\quad($ mean $=5.9$ g; $\quad \mathrm{SD}=0.9)$, cheese $($ mean $=4.5 \mathrm{~g} ; \mathrm{SD}=0.9)$, and rat chow (mean $=8.7 \mathrm{~g} ; \mathrm{SD}=0.7$ ) arranged side by side in randomized order in its overhead food bin. Each crab received preweighed portions of DNM (mean $=5.0 \mathrm{~g} ; \mathrm{SD}=0.6)$, coconut $($ mean $=14.3 \mathrm{~g} ; \mathrm{SD}=3.7)$, and omnivore $\operatorname{diet}($ mean $=4.2 \mathrm{~g} ; \mathrm{SD}=1.0)$ placed in separate cups in its cage. Bait consumption was checked the following morning, and any remaining baits were individually reweighed (corrected for change in bait mass not eaten). 
Experiment 3: Abilities to Access Bait Stations in Simulated Field Placement Situations

This was the primary experiment in the study. Animals were tested for their ability to access three different types of bait stations in three placement situations used in Guam. The following bait stations were provided by the U.S. Department of Agriculture, Wildlife Services (WS), Guam (Figure 1):

1. PVC pipe, $30.5 \mathrm{~cm}$ in length, $5.1 \mathrm{~cm}$ inner diameter, open at each end, suspended horizontally from support structures by nylon cord (" 2 by 12 " hereafter). This design is identical to that used widely in current snake control operations on Guam (Figure 1a).

2. $P V C$ pipe, $30.5 \mathrm{~cm}$ in length, $10.2 \mathrm{~cm}$ inner diameter, removable cap at one end, suspended at a $\sim 45^{\circ}$ angle with the open end downward (" 4 by 12 " hereafter). A stainless-steel wire-mesh screen affixed to the inside of the tube below the tube cap served as a bait holder (Figure 1b).

3. PVC pipe, $30.5 \mathrm{~cm}$ in length, $5.1 \mathrm{~cm}$ inner diameter, fitted at one end with a PVC expansion fitting (Clean-out), removable cap, and suspended with open end downward at a $\sim 60^{\circ}$ angle ("C-O" hereafter). The internal bait holder was similar to that described in no. 2 (Figure 1c).

Bait stations were suspended from three different support structures, simulating placement situations commonly used in the field (Figure 2):

1. Vegetation ("Vegetation" hereafter [Figure 2a]). Sizable areas of northern Guam consist of secondary thickets and scrub forest (Mueller-Dombois and Fosberg 1998), and most snake control is conducted in such areas, where bait stations are suspended from vegetation $\sim 1.4 \mathrm{~m}$ above ground. We simulated this vegetation type (very simplistically) by affixing sections of $1.5-$ to $2.5-\mathrm{cm}$ diameter cottonwood branches on all three arms of a triangu-

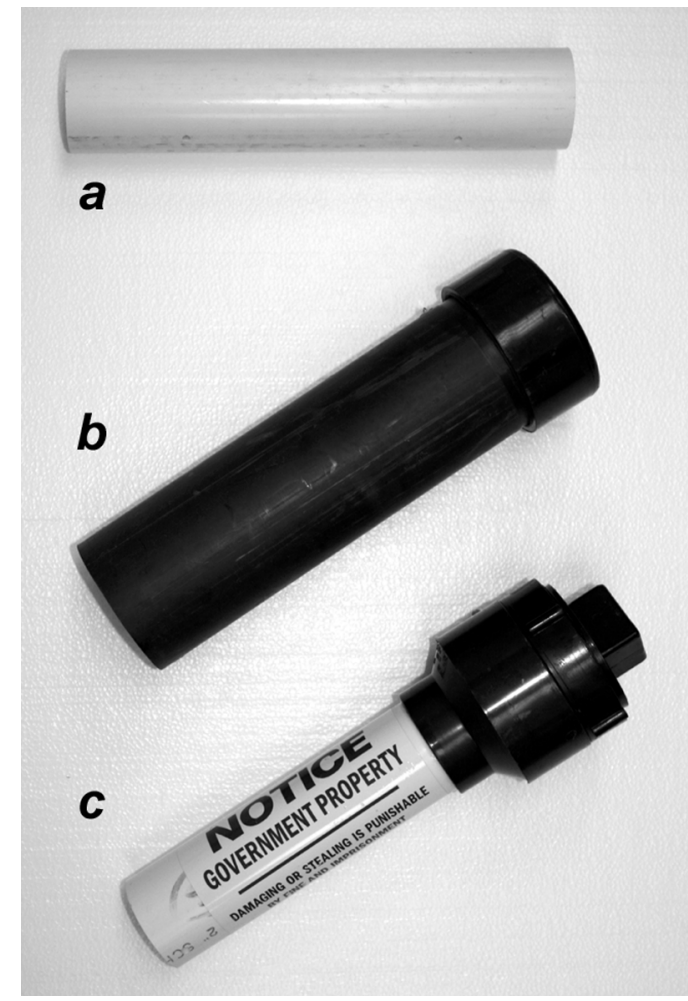

Figure 1. Brown tree snake (Boiga irregularis) bait station types tested in this study. $a$, " 2 by 12 " station, placed horizontally, both ends open. This is the station type used most widely on Guam for operational snake eradication; $b$, " 4 by 12 " station, placed at $\sim 45^{\circ}$ angle, lower end open; $c$, "C-O" station, placed at $\sim 60^{\circ}$ angle, lower end open.

lar wooden framework (Figure $3 a$ ). The upper arm of the structure was oriented horizontally, spanning the length of the chamber, and was situated $1.5 \mathrm{~m}$ above the chamber floor. A second arm was oriented vertically, connecting one end of the upper arm to the chamber floor. The third arm completed the triangle on the diagonal. The bait station was suspended horizontally from the upper arm (if " 2 by 12" bait station type) or from its capped end with the lower open end affixed to the midpoint of the diagonal arm (if the other two station types). Bait stations were situated 1.0-1.2 $\mathrm{m}$ above the chamber floor. 

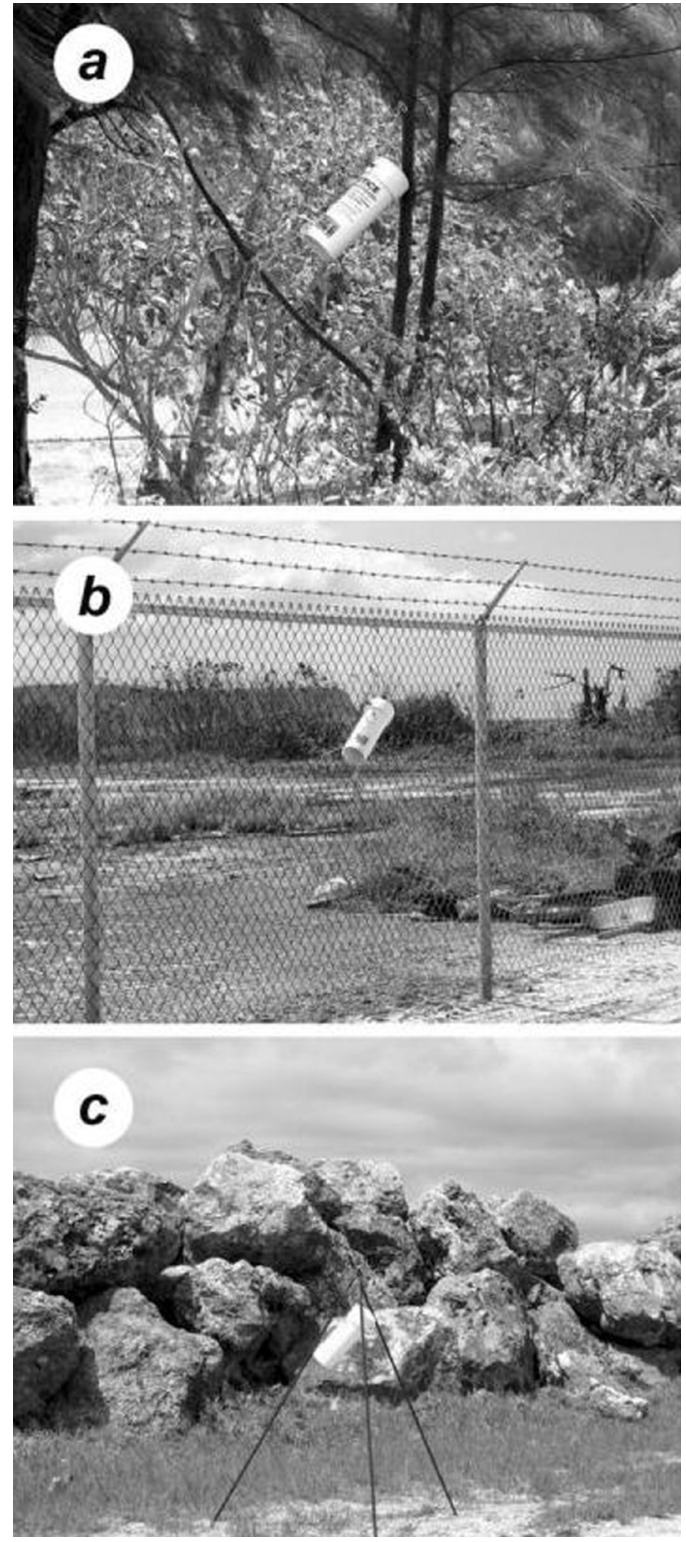

Figure 2. Representative operational placement situations of brown tree snake (Boiga irregularis) bait stations on Guam. Bait station attached to: $a$, vegetation; $b$, chainlink cyclone fence; and $c$, rebar tripod. Bait stations shown in each panel are the " 4 by 12 " station type but were made from white, rather than black, PVC pipe.
2. Metal chain-link cyclone fence ("Fence" hereafter [Figure 2b]). Snake control on Guam is often conducted in and around military facilities where perimeter fencing is commonly accessed by snakes and provides a convenient station support structure. To simulate this support type we cut 1.5 -m-high cyclone fence into sections spanning the long axes of chambers (Figure $3 b$ ). Each section was affixed by its top edge to a wooden crossbar situated $1.5 \mathrm{~m}$ above the floor of each chamber and $40 \mathrm{~cm}$ from the chamber front. The bait station was affixed at about midpoint along the long axis of the section $1.0-1.2 \mathrm{~m}$ above the chamber floor.

3. Metal rebar tripod ("Tripod" hereafter [Figure $2 c]$ ). In areas without convenient support structures, bait stations are suspended from rebar tripods. Tripods used in this study were the same as used operationally on Guam. Each consisted of three $1.5-\mathrm{m}$-long sections of steel rebar lashed together with steel wire at their upper ends, standing $1.2 \mathrm{~m}$ at the apex (Figure 3c). The bait station was suspended below the apex of the tripod roughly $85 \mathrm{~cm}$ above the chamber floor.

We evaluated rats using eight large test chambers in a room with environmental conditions similar to those in their maintenance room. We used four additional identical chambers inside the room where crabs were housed to evaluate crabs. Chambers were fabricated from galvanized steel and measured $1.1 \mathrm{~m}$ wide, $0.9 \mathrm{~m}$ deep, and $1.7 \mathrm{~m}$ high. Ventilation was provided by numerous 0.6 -cm-diameter holes in chamber tops and three sides (floor drains were also provided for crabs). The front of each chamber consisted of a 0.9-cm-thick plastic Lexan (SABIC Innovative Plastics, Riyadh, Saudi Arabia) door allowing a clear view into all areas of the chamber. We filmed animal activity within each cage using a video camera equipped with infrared illuminators attached to a time-lapse video recorder. We provided 

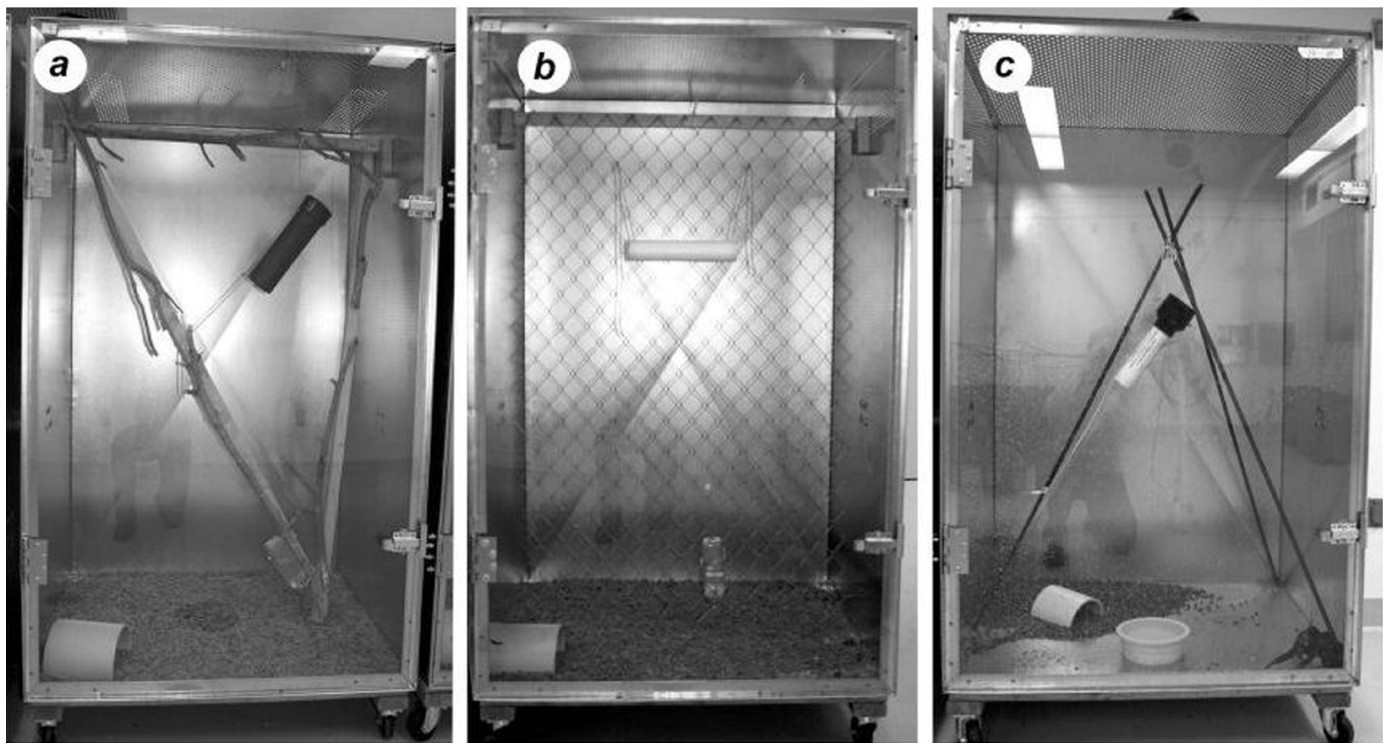

FIGURE 3. Test chambers containing brown tree snake (Boiga irregularis) bait stations in different placement situations. $a$, " 4 by 12 " station, placed at $\sim 45^{\circ}$ angle on simulated vegetation; $b$, " 2 by 12 " station, placed horizontally on chainlink cyclone fence; $c$, "C-O" station, placed at $\sim 60^{\circ}$ angle on rebar tripod. Stations are hung from support structures using nylon cord.

chambers with water ad libitum and the same substrate type used in maintenance cages.

We randomly assigned each animal to one of three structure types with the restriction that numbers of individuals and members of each sex within species assigned to each structure type be as equal as possible. The order in which each individual was tested with each of the three bait station types was randomized. Three days before an animal was tested, we transferred it from its maintenance cage into the assigned test chamber containing the designated structure type. The animal was then allowed to acclimate to the chamber and structure type for 3 days, during which time water (ad libitum) and a daily rodent chow allotment were provided (Rattus spp. only). Evaluation of bait station use began 4 days after an animal was placed in a test chamber. On that day, we secured the designated bait station type into position on the structure type within the chamber. We weighed portions of the "preferred" baits of each species (bait amounts similar to those provided in
Experiment 2; chow not included) and placed them inside at the midpoint of the horizontal station or in the bait holder of the other station types. We activated video recorders. The following morning, we switched off video recorders, replaced the tape, and checked bait stations for signs of bait consumption. Baits were not weighed; we noted only whether or not consumption had occurred. We repeated this process for 2 nights, each time changing the designated station type (thus, three consecutive test nights per individual, replacing the bait station with a different type each night). At the end of the trial, we returned the animal to its maintenance cage. We washed chambers out with hot water. The possible effect of animal scent in chambers from previously tested animals is acknowledged, and unknown, but would have been similar among chambers. Structure types, bait stations, and all other materials used in the chambers were removed and cleaned in a tunnel cage washer (Steris Basil 4600) or a larger cage washer (Steris Basil 6000) (Steris 
Corp., Beauport, Canada), as appropriate. Testing continued in this manner until all individuals had been tested, resulting in 36,36 , and 30 rat-test nights for roof rats, Norway rats, and Polynesian rats, respectively, and 48 test nights for crabs.

We reviewed each videotape on a largescreen television. For each animal we recorded whether or not it entered the bait station. Bait was considered "taken" if there was any consumption. Review of tapes indicated that all species became active as soon as the room lights switched off, and activity occurred until lights switched on the following morning. Because of the continuous activity of all rat species, we limited data collection to the first hour of room darkness, recording the number of times an animal investigated the open end of a bait station. Crabs were much less active than rats, so we collected data on their activity over the entire $12 \mathrm{hr}$ of darkness.

\section{Experiment 4: Abilities to Access Bait Stations When External Impediments Are Removed}

This experiment tested abilities of animals to enter each bait station type without the added difficulty of station placement used in Experiment 3. The experiment was conducted following Experiment 3, so that animals in that experiment were naive to bait stations. In this experiment, we made each bait station as accessible as possible by suspending it such that the bottom edge of the station entrance was situated $\sim 2 \mathrm{~cm}$ above the test chamber floor. All three station types were suspended side by side within each chamber. The order in which individuals were tested was randomized. As in Experiment 3, we placed each animal within a chamber provided with chow and water and allowed it to acclimate to the chamber (and the three stations within) for three consecutive days. On the fourth day, we baited all stations within chambers, checked for bait take the following morning, and then rebaited as in Experiment 3. We tested each animal for four consecutive nights. Chambers and stations were cleaned between test subjects as in Experiment 3. Co- conut crabs were not included in this experiment because none accessed stations in Experiment 3. At the end of this experiment, we returned each animal to its maintenance cage and tested for the possibility that it had become refractory to bait used in this experiment and possibly Experiment 3. This determination was made by offering each individual the same bait types it had received previously (including rodent chow) and noting take, following methods used in Experiment 2. All testing was completed on 14 July 2008.

\section{Statistical Analyses}

Unless noted, all analyses were conducted using generalized linear mixed models (GLMM) with the GLIMMIX procedure in program SAS (Version 9.2, SAS, Cary, North Carolina). In Experiment 1, percentage DNM mass consumed was the response variable, DNM treatment (Fresh DNM, Aged DNM) and day (Day 1, Day 2) were the fixed effects, and blocking was by individual animal. In Experiment 2, the response variable was percentage bait mass consumed, bait type was the fixed effect, and design was blocked by individual animal. Separate analyses were conducted by species. The omnivore chow for crabs absorbed considerable water vapor overnight, and masses consumed could not be determined reliably. These data were therefore not included in this analysis.

In Experiment 3, nontargets rarely accessed baits inside stations so data are presented in tabular form, and the effect of bait station type and station were analyzed using a chi-square test. We performed other statistical tests using accession of the station entrance as the response variable. Accession of the station entrance was a measure of the ability of a species to reach a station (but not necessarily negotiate its interior) given the unique orientation of each bait station type on each structure type. Whole-plot treatment effects were species and structure, the splitplot effect was station type, and blocking was by individual animal and week. We analyzed data for roof rats separately because 
individuals accessed entrances of every type in every placement situation; thus in this analysis, structure was the only whole-plot treatment effect. In both analyses, preliminary analyses revealed no day effect, and this term was not included in the final models. For significant effects in models, we conducted pairwise comparisons of least-squares means using the Tukey-Kramer adjustment (Zar 1984). In the fifth week of this experiment, one roof rat, one Norway rat, and three crabs remained to be tested, and because the analyses were blocked by week we did not include data for these individuals in the analyses.

In Experiment 4, the response variable was take of bait inside station. These data were analyzed by species, blocking for week and individual animal. The full model could not be employed because of lack of convergence for one species (Norway rats) and was best rectified using an alternative model where a random two-way interaction effect (Day $\times$ Station Type) was excluded. Response variables in Experiments 3 and 4 were binary, and the logit transformation was used. Results are presented as least-squares mean probabilities $( \pm \mathrm{SEM})$, expressed as percentages, of accessing station entrance and accessing the bait inside the station, respectively. Statistical significance in all analyses was set at $P \leq .05$.

\section{RESULTS}

\section{Experiment 1}

Roof rats and Norway rats (but not Polynesian rats or crabs) consumed greater percentage masses of Fresh DNM than Aged DNM regardless of the day (order) on which it was received, and all rat species except Norway consumed less DNM on Day 2 than on Day 1 (Figure 4 ). The DNM type $\times$ Day interaction was significant for roof rats and Polynesian rats but not for Norway rats or coconut crabs (Table 1). Causal bases of the interaction effects for roof rats and Polynesian rats were as follows: Roof rats that received Aged DNM on Day 1 consumed amounts nearly equal to Fresh DNM consumed by other roof rats on Day 1 . However, they ate consid-

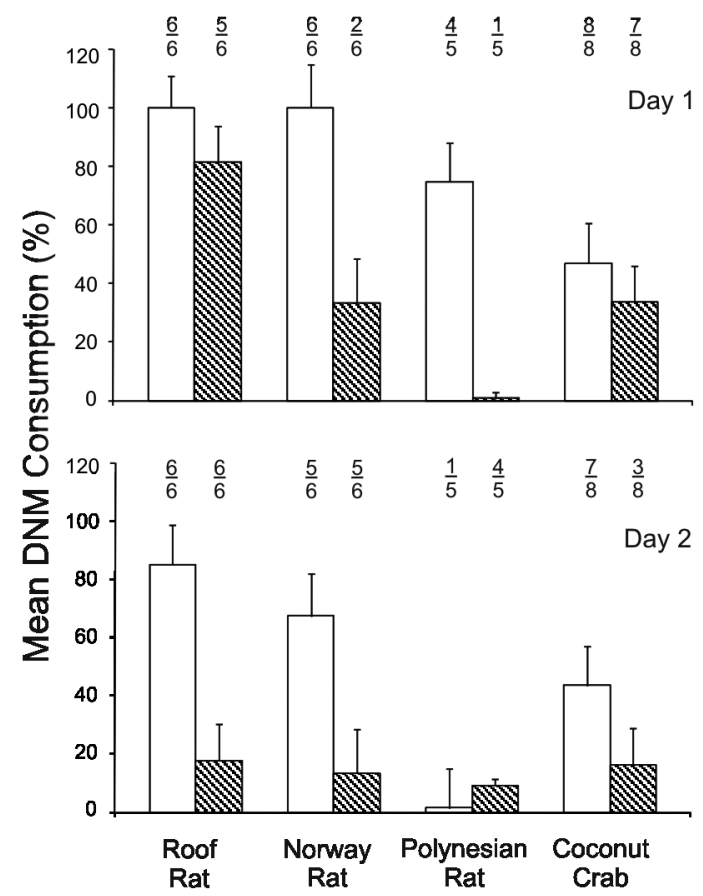

Figure 4. Experiment 1: Mean percentage consumption of Fresh (open bars) and Aged (stippled filled bars) (see Materials and Methods) dead neonatal mice (DNM) baits over two consecutive days (Day 1, Day 2) by roof rats (Rattus rattus), Norway rats (Rattus norvegicus), Polynesian rats (Rattus exulans), and coconut crabs (Birgus latro). A counterbalance design was used wherein each individual was presented with one bait type on Day 1 and then presented with the other type on Day 2. Least-squares means $( \pm$ SEM $)$ are presented. Numerators and denominators of fractions above each bar indicate number of individuals that consumed that bait type and number of individuals offered that bait type, respectively.

erably less Aged DNM when offered on Day 2. Polynesian rats consumed relatively little Aged DNM on Day 1, whereas consumption of Fresh DNM on Day 1 was high. On Day 2 , however, the direction of this pattern was reversed, with somewhat higher consumption of Aged than Fresh DNM, although amounts consumed in both treatments were low. Consumption of Aged DNM by Polynesian rats was lower than that of any other species, whereas consumption by roof rats was highest. Based on overall findings of this experiment, all nontarget species were included in the remainder of the experiments (coconut 
TABLE 1

Experiment 1: Results of Generalized Linear Mixed Model Type III Significance Tests for Effects of Dead Neonatal Mouse (DNM) Bait Type (Aged or Fresh [see Materials and Methods]), Day, and Interaction Effect on Consumption in Roof Rats (Rattus rattus), Norway Rats (Rattus norvegicus), Polynesian Rats (Rattus exulans), and Coconut Crabs (Birgus latro)

\begin{tabular}{|c|c|c|c|c|}
\hline Species & $n$ & DNM Type & Day & DNM Type $\times$ Day \\
\hline Roof rat & 12 & $\begin{array}{c}F=13.7 ; \mathrm{df}=1,19.5 \\
P=.001\end{array}$ & $\begin{array}{c}F=11.5 ; \mathrm{df}=1,19.5 \\
P=.003\end{array}$ & $\begin{array}{c}F=4.4 ; \mathrm{df}=1,19.5 \\
P=.049\end{array}$ \\
\hline Norway rat & 12 & $\begin{array}{c}F=16.5 ; \mathrm{df}=1,19.9 \\
P=.001\end{array}$ & $\begin{array}{c}F=3.1 ; \mathrm{df}=1,19.9 \\
P=.092\end{array}$ & $\begin{array}{c}F=0.2 ; \mathrm{df}=1,19.9 \\
P=.667\end{array}$ \\
\hline Polynesian rat & 10 & $\begin{array}{c}F=12.0 ; \mathrm{df}=1,8.4 \\
P=.008\end{array}$ & $\begin{array}{c}F=11.5 ; \mathrm{df}=1,8.4 \\
P=.009\end{array}$ & $\begin{array}{c}F=18.2 ; \mathrm{df}=1,8.4 \\
P=.003\end{array}$ \\
\hline Coconut crab & 16 & $\begin{array}{c}F=2.5 ; \mathrm{df}=1,27.8 \\
P=.128\end{array}$ & $\begin{array}{c}F=0.6 ; \mathrm{df}=1,27.8 \\
P=.436\end{array}$ & $\begin{array}{c}F=0.3 ; \mathrm{df}=1,27.8 \\
P=.599\end{array}$ \\
\hline
\end{tabular}

Note: Each individual was presented with one type of DNM bait on the first day (Day 1) and the other type on the next day (Day 2). $n$, sample size.

crabs were excluded from Experiment 4), and Fresh DNM, rather than Aged, was used in all further experiments.

\section{Experiment 2}

Mean percentage mass of bait type consumed varied for roof rats $(F=45.5$; df $=3,12.6$; $P<.001)$ and Norway rats $(F=7.6 ; \mathrm{df}=3$, $15.5 ; P=.002)$, but not for Polynesian rats $(F=2.3 ; \mathrm{df}=3,16.8 ; P=.117)$ or coconut crabs $(F=4.2 ;$ df $=1,23.7 ; P=.052)$, although the $P$-value for the latter was suggestive of a difference in consumption (Figure 5). Roof rats consumed more DNM than peanut butter-oat mixture, cheese, or rat chow, but proportions consumed did not vary among the latter three bait types. Norway rats consumed more peanut butter-oat mixture than rat chow, but all other pairwise comparisons were not significantly different. Results for Polynesian rats were equivocal primarily because four of the 10 individuals did not consume any of the bait types presented. Coconut crabs showed a tendency to consume more DNM than coconut. Based on these results, baits used in Experiments 3 and 4 were DNM (all species), peanut butter-oat mixture (all rat species), and cheese (Polynesian rats). We could not quantify consumption of omnivore chow by crabs due to increase in chow mass by water vapor absorption, but visual inspection suggested greater consumption of chow than coconut. Therefore crabs received omnivore chow along with DNM in Experiment 3.

\section{Experiment 3}

The number of individuals of each rat species that accessed baits within stations was limited; only one Polynesian rat accessed a bait (Table 2), with most accessions by roof rats and Norway rats. No crabs accessed baits. Accessions of bait differed between bait station type and station placement situation $\left(\chi^{2}=9.7, \mathrm{df}=4, P=.046\right)$. Stations placed on fence had over three times as many accessions as those in the other two placement situations. Standard bait stations ( 2 by 12 ) were accessed on over twice as many occasions as the other two station types. The 4 by 12 and C-O station types were accessed on only one occasion each in the Tripod and Vegetation placement situations. However, videotape observations showed that none of the individuals that accessed baits had difficulty entering stations and reaching baits once they committed.

In contrast to the number of individuals that entered and took baits from stations, individuals of all species accessed station entrances on many occasions, particularly roof rats. In the separate analysis for roof rats, there were no significant effects for station type $(F=0.0 ; \mathrm{df}=2,24 ; P=.99)$, structure 


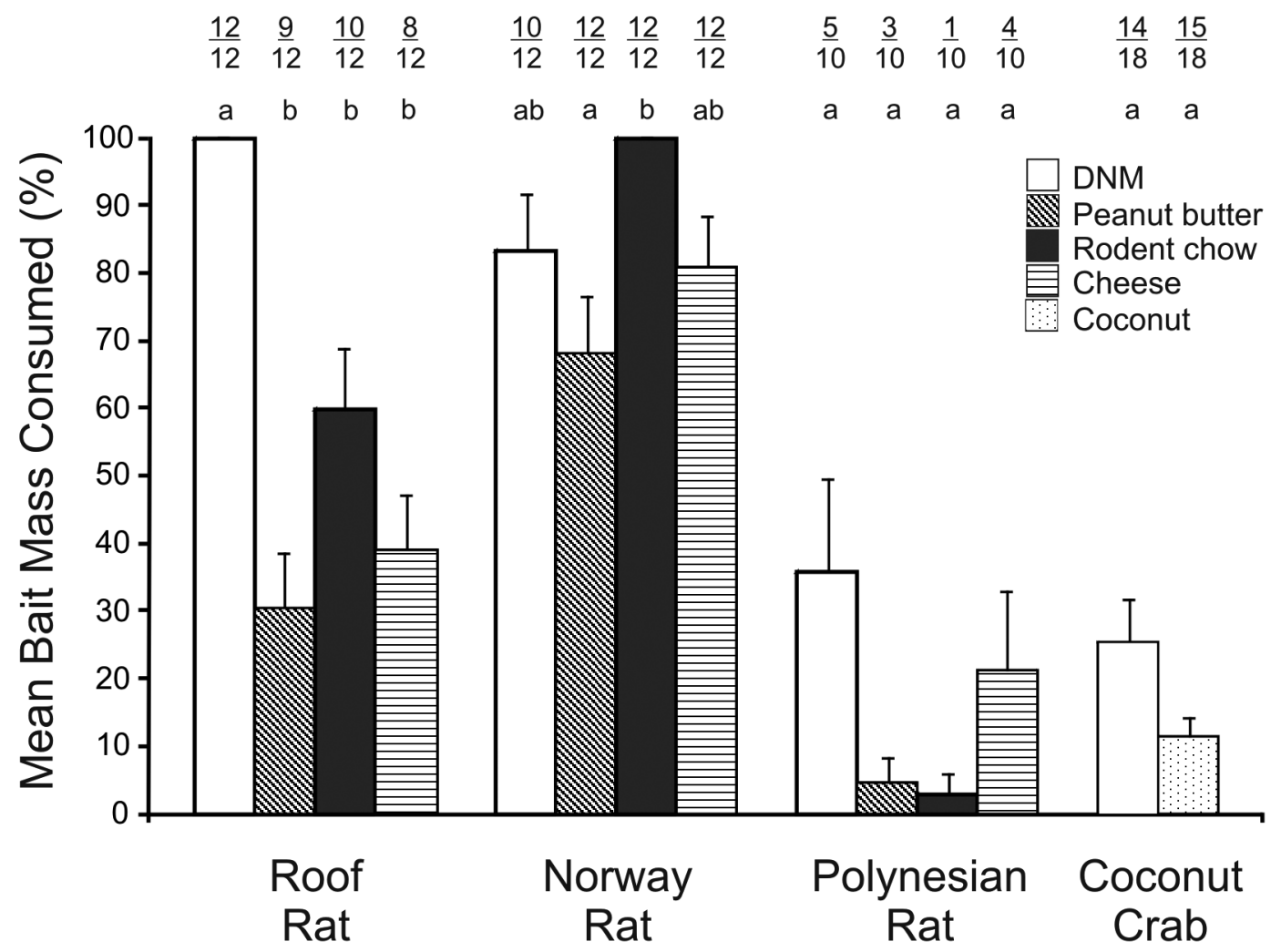

Figure 5. Experiment 2: Mean percentage bait mass consumed for baits presented simultaneously on 1 day for roof rats (Rattus rattus), Norway rats (Rattus norvegicus), Polynesian rats (Rattus exulans), and coconut crabs (Birgus latro). Least-squares means $( \pm$ SEM) are presented. Within species, bait types with significantly different means $(P<.05)$ are designated with different letters located above the bars. Numerators and denominators of fractions above each bar indicate number of individuals that consumed that bait type and number of individuals offered that bait type, respectively. DNM, dead neonatal mouse.

type $(F=0.0 ; \mathrm{df}=2,24 ; P=.99)$, or interaction effect $(F=0.0 ; \mathrm{df}=2,24 ; P=1.00)$. Least-squares mean probabilities for accession of station entrances of 2 by 12,4 by 12 , and $\mathrm{C}-\mathrm{O}$ stations were $1.00 \pm 0.00$, $0.99 \pm 1.04$, and $1.00 \pm 0.00$, respectively; those for structure types Tripod, Fence, and Vegetation were $1.00 \pm 0.00,1.00 \pm 0.01$, and $0.99 \pm 0.90$, respectively. In the analysis for accession of station entrance for all other species, there was a significant effect for station type $(F=3.5 ; \mathrm{df}=2,69 ; P=.036)$ but not for species $(F=1.5 ;$ df $=2,20$; $P=.239)$, structure type $(F=1.2 ; \mathrm{df}=2$, $20 ; P=.322)$, or the interaction effect $(F=0.9 ; \mathrm{df}=4,69 ; P=.492)$. Of the three bait station types, the $\mathrm{C}-\mathrm{O}$ station had the lowest mean probability of an animal accessing the station entrance, followed by the 4 by 12 and then the 2 by 12 stations, but mean probabilities differed only between $\mathrm{C}-\mathrm{O}$ and 2 by 12 station types (Figure 6). The C-O station, when used in conjunction with vegetation support, proved to be the most difficult bait station configuration to access for all species. Animals were able to access this configuration only $30 \%$ of the time.

\section{Experiment 4}

Probabilities of bait take from all bait station types were low for both roof rats and Norway 
TABLE 2

Experiment 3: Cases of Bait Take from Each Station Type in Each Placement Situation by Roof Rats (Rattus rattus), Norway Rats (Rattus norvegicus), Polynesian Rats (Rattus exulans), and Coconut Crabs (Birgus latro)

\begin{tabular}{|c|c|c|c|c|}
\hline \multirow[b]{2}{*}{ Station Type } & \multirow[b]{2}{*}{ Species } & \multicolumn{3}{|c|}{ Station Placement Situation ${ }^{a}$} \\
\hline & & Tripod & Fence & Vegetation \\
\hline \multirow[t]{4}{*}{2 by 12} & Roof rat & $1(3)$ & $3(4)$ & $3(4)$ \\
\hline & Norway rat & $2(4)$ & $2(4)$ & $0(3)$ \\
\hline & Polynesian rat & $0(3)$ & $1(3)$ & $0(4)$ \\
\hline & Coconut crab & $0(5)$ & $0(5)$ & $0(5)$ \\
\hline \multirow[t]{4}{*}{4 by 12} & Roof rat & $1(3)$ & $0(4)$ & $0(4)$ \\
\hline & Norway rat & $0(4)$ & $3(4)$ & $0(3)$ \\
\hline & Polynesian rat & $0(3)$ & $0(3)$ & $0(4)$ \\
\hline & Coconut crab & $0(5)$ & $0(5)$ & $0(5)$ \\
\hline \multirow[t]{4}{*}{$\mathrm{C}-\mathrm{O}$} & Roof rat & $0(3)$ & $2(4)$ & $1(4)$ \\
\hline & Norway rat & $0(4)$ & $2(4)$ & $0(3)$ \\
\hline & Polynesian rat & $0(3)$ & $0(3)$ & $0(4)$ \\
\hline & Coconut crab & $0(5)$ & $0(5)$ & $0(5)$ \\
\hline
\end{tabular}

${ }^{a}$ Values in parentheses are total possible cases of bait take.

rats but were high for Polynesian rats (Figure 7). For roof rats, mean probability of bait take did not vary among station types $(F=0.7 ; \mathrm{df}=2,138 ; P=.509)$, and the Day effect was not significant $(F=1.2$; $\mathrm{df}=3,138 ; P=.313)$. For Norway rats, probability of accessing bait varied among station types $(F=5.4 ; \quad \mathrm{df}=2,127 ; P=$ .006), but the Day effect was not significant $(F=2.2 ; \mathrm{df}=3,127 ; P=.091)$. For Polynesian rats, probability of accessing bait did not vary among station types $(F=0.2 ; \mathrm{df}=$ $2,105 ; P=.777)$, but the Day effect was significant $(F=4.6 ; \mathrm{df}=3,105 ; P=.004)$, with mean probabilities for take increasing each consecutive day (e.g., .50 $\pm .19, .63 \pm$ $.27, .93 \pm .07, .97 \pm .03$ [Days $1-4$, respectively]). Mean percentage consumption of bait in maintenance cages of rats at the conclusion of this experiment is shown in Table 3. All three rat species showed good bait acceptance, with percentage consumptions similar to those observed in Experiment 2 .

\section{DISCUSSION}

All species in this study readily consumed DNM, and except for most Polynesian rats, even DNM that were putrid. Thus, there is impetus for each species to attempt to access DNM in bait stations in the field. Coconut crabs consumed less Fresh DNM than the other species but perhaps only because of their relatively smaller body sizes and lower metabolic requirements. Consumption of DNM by all four species is not surprising because all three rat species are known to consume animal material (Bull 1972, Pervez et al. 1999, Nelson et al. 2002). Coconut crabs are primarily scavengers and are known to feed on carrion (Reyne 1939, Gibson-Hill 1947, Grubb 1971). In our study, all species consumed more Fresh than Aged DNM. However, take of Aged DNM was also substantial in all species tested except Polynesian rats. Both these findings are potentially problematic because take of DNM by brown tree snakes is greater on the second night in the field than on the first night, probably because volatiles from a decomposing DNM are easier for brown tree snakes to detect than those from fresh DNM (Jojola-Elverum et al. 2001). Thus, if nontargets are better than snakes at locating DNM on the first day deployed, their bait take could be appreciable, and they would continue to compete for DNM on subsequent days as bait aged. However, our finding of a mild satiety effect in the rat species by the second night of DNM 


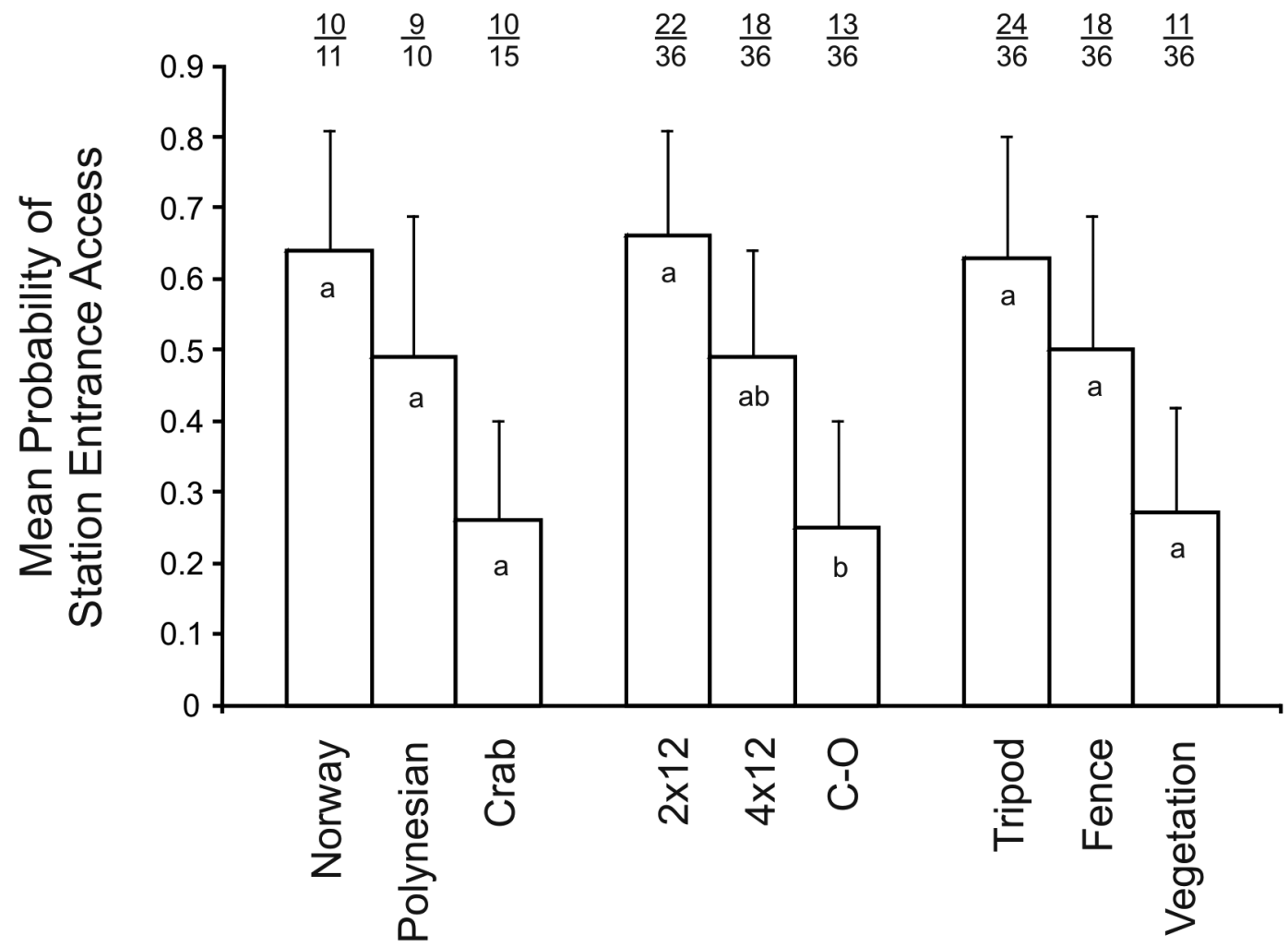

\section{Species Station Type Structure Type}

FIgURE 6. Experiment 3: Mean probabilities of accessing bait station entrance for Norway rats (Rattus norvegicus), Polynesian rats (Rattus exulans), and coconut crabs (Birgus latro). In this experiment stations were suspended from support structures above test chamber floor (see Materials and Methods). Least-squares means $( \pm S E M)$ are presented. Within species, station type, or structure type effects, significantly different means $(P<.05)$ are designated with different letters located within bars. Numerators and denominators of fractions above each bar indicate number of individuals that accessed a station entrance and number of individuals tested, respectively.

consumption (Experiment 1) also raises the possibility that take might be somewhat mitigated in a long-term operational effort where DNM are replaced every 3 days.

What insights do our results provide on exclusion potentials of the three bait station types in the field and placement situations that best enhance their efficiencies? Results from Experiment 4, where bait stations were purposefully made easily accessible, provide a good starting point for these assessments; probabilities for bait take from all bait station types were surprisingly low for both roof rats and Norway rats but uniformly high for Polynesian rats. We expected the former two species to have high bait take from at least the 2 by 12 station, because it presented no obvious physical obstacles to access and had two entrances rather than one. Norway rats did take baits more frequently from this station type compared with the other two, but there were only 14 such cases. Bait take by roof rats did not vary among station types. These findings may be indicative of neophobia toward stations per se by roof rats and Norway rats or simply the need for a longer acclimation 


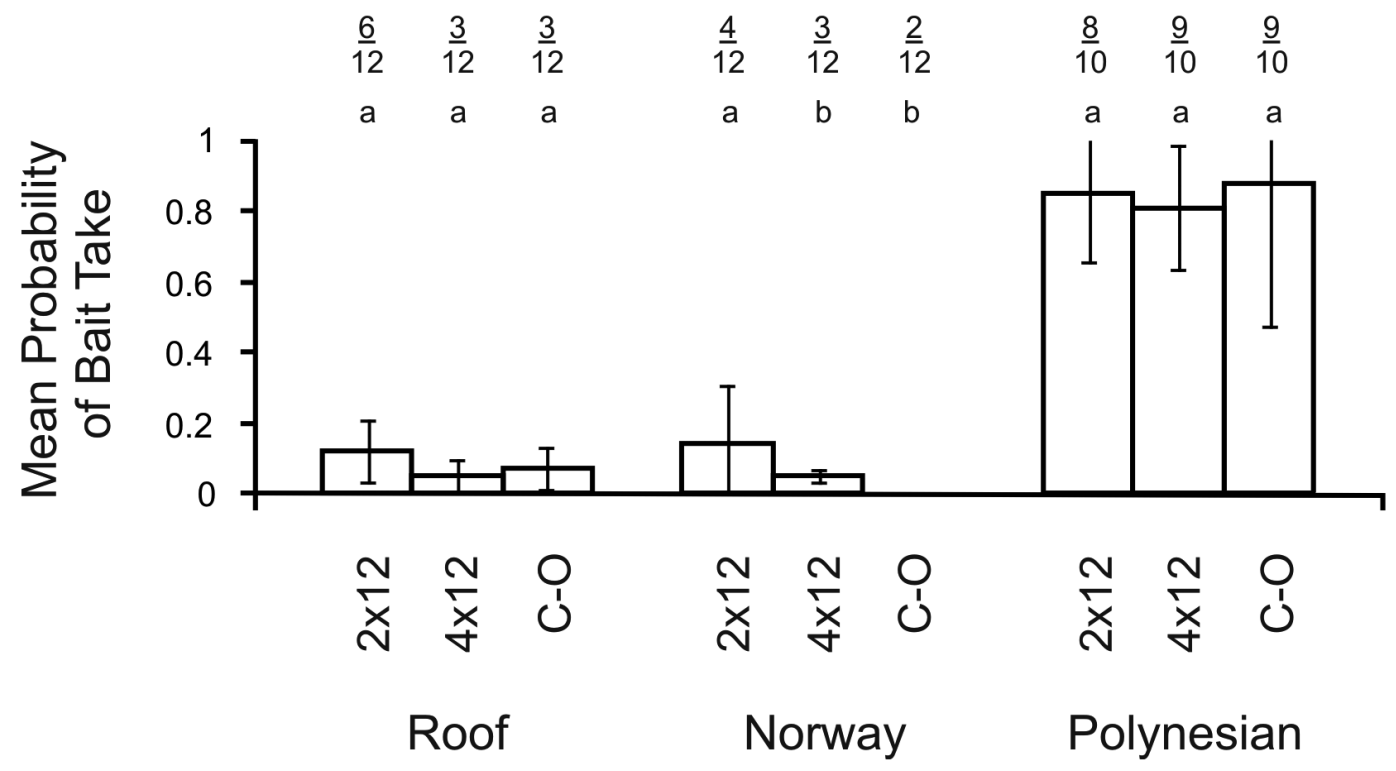

FIgURE 7. Experiment 4: Mean probabilities of bait consumption for roof rats (Rattus rattus), Norway rats (Rattus norvegicus), and Polynesian rats (Rattus exulans) from three bait station types (designated " 2 by 12 ," "4 by 12," and "C-O" [see Materials and Methods]) over four consecutive days. In this experiment stations were made easily accessible by suspending them close to the floor of the test chamber (see Materials and Methods). Least-squares means $( \pm$ SEM) are presented. Error bars have been truncated at 0 and 1 . Number above each bar indicates number of times a station type was entered and bait consumed. Within species, significantly different means $(P<.05)$ among station types are designated with different letters located above the bars.

TABLE 3

Experiment 4: Validation of Continued Bait Acceptance by Roof Rats (Rattus rattus), Norway Rats (Rattus norvegicus), and Polynesian Rats (Rattus exulans)

\begin{tabular}{|c|c|c|c|}
\hline \multirow[b]{2}{*}{ Species } & \multirow[b]{2}{*}{$n$} & \multicolumn{2}{|c|}{$\begin{array}{l}\text { Mean Percentage Bait } \\
\text { Mass Consumed } \pm \text { SD }\end{array}$} \\
\hline & & DNM & $\mathrm{PB}$ \\
\hline Roof & 12 & $89.8 \pm 24.5(11)$ & $81.8 \pm 31.9(11)$ \\
\hline Norway rat & 12 & $86.9 \pm 30.7(11)$ & $100 \pm 0.0(12)$ \\
\hline Polynesian rat & 10 & $50.2 \pm 30.4(5)$ & $52.8 \pm 31.4(8)$ \\
\hline
\end{tabular}

Note: DNM, dead neonatal mouse; PB, peanut butter-oat mixture; $n$, sample size; SD, standard deviation; parentheses enclose number of cases where bait was taken.

period. Although the trend only approached statistical significance $(P=.091)$, probability of entering a station for Norway rats regularly increased over the four consecutive test days. By contrast, this increasing trend was strongly supported for Polynesian rats, where bait take on Day 4 was double that on Day 1. Depending on the population and type of environment, roof rats can be neophobic toward bait stations, taking several weeks to enter (Howard 1987) or entering in only 1 to 2 days (Advani and Idris 1982). Populations of Norway rats that are commensal can be particularly neophobic toward bait stations, but there is little such information for Polynesian rats (for review, see Clapperton [2006]). In our study, any neophobia quickly subsided over the 4-day test period.

Results from Experiment 3 provide insight into how station support structures chosen in the environment might affect nontarget access of the different station types. First, similar to results from Experiment 4, the number of cases of bait take from stations was low overall (21\%; 21 cases per 102 rat test nights). For the three rat species taken together, bait 
take from the 2 by 12 station on the Fence configuration was more than twice as high as each of the other four configurations. Overall, take by roof rats and Norway rats was similarly low (11\% and $9 \%$, respectively). In sharp contrast to results from Experiment 4, there was only one case of station accession for Polynesian rats. These numbers for roof rats and Norway rats do not differ greatly from those obtained on Day 1 of Experiment 4 , suggesting that it was not station placement structure that hindered station access. Observations on species accessions of station entrances further illuminate the interaction between station type and placement structure; for roof rats, probabilities for accession of station entrance were essentially unity for all station types in all placement situations. This suggests that there may be no practical placement situation in the environment for any of the station types tested that would prevent individuals of this species from accessing station entrances. This, however, may be mitigated by the findings in Experiments 3 and 4 of the apparent limited disposition of roof rats to enter stations to take baits. The three other nontarget species evaluated in Experiment 3 accessed entrances to stations with much lower frequencies than roof rats, and interspecies probabilities of accession did not vary significantly. Probabilities also did not vary among station placement structure types, but nontargets did access entrances of C-O stations less than those of the 2 by 12 stations. Thus, the $\mathrm{C}-\mathrm{O}$ station seems to be the best design for mitigating accessions by Norway rats but not necessarily of roof rats. Polynesian rats largely either were unable to enter stations or chose not to enter stations, once the stations had been suspended above ground. As agile as Polynesian rats were observed to be on the videotapes, it is difficult to believe that they could not easily enter and negotiate the angled stations. There were no cases of bait take by coconut crabs, and crabs had the lowest probability of accessing station entrances. This probability was lower than for the three rat species even though observations for crabs were taken from a 12-hr period each night versus a $1-\mathrm{hr}$ period for all rat species. We conclude that take of DNM baits by Polynesian rats during operational use would be low and tentatively conclude the same for coconut crabs; however, in contrast to crabs used in this study, some of those in the field on Guam had noticeably shrunken abdomens where fat is stored (T.M., pers. obs.), and crabs in this condition may be more motivated to access baits.

How well do the abilities of the nontarget species in this study to negotiate station support structures match their known degrees of aboreality? All four nontarget species in this study are documented climbers. Previous studies have found roof rats to be efficient climbers, with higher recapture rates and bait take occurring above ground than on the ground (Tobin et al. 1997, Nelson et al. 2002, Spurr et al. 2007). The Polynesian rat is considered less arboreal than the roof rat (Lindsey et al. 1999) but is known to nest and feed in trees (Daniel 1969, McCartney 1970, Williams 1973, Moors et al. 1992). Norway rats are also considered less arboreal than roof rats (Atkinson 1985, Key and Woods 1996). In one study, capture rates of Norway rats were greater below ground than above ground (Spurr et al. 2006). Norway rats are also known for their extensive habit of burrowing (Spurr et al. 2006), suggesting that it is the least arboreal of the rat species we tested. Although coconut crabs utilize burrows, they are also well adapted to climbing, albeit slowly, and are often observed feeding in Pandanus and Ficus trees (Grubb 1971). Numerous other field accounts, as discussed in Reyne (1939), indicate that coconut crabs have good climbing abilities. Thus, of the three rat species we studied, the roof rat is probably the most arboreal, which is in line with our findings. Unfortunately, recent surveys raise the possibility that the roof rat (or the closely related $R$. diardii [Wiewel et al. 2009]) may be by far the most common of the three rat species on Guam (Wiewel et al. 2009). The Polynesian rat is probably more arboreal than the Norway rat, but this was not evident in our study. Coconut crabs, although they were able to reach station en- 
trances, may have difficulty gaining footholds on the smooth interiors of downward-angled stations and would probably have to brace themselves against the sides of a station to move upward toward the bait compartment. However, when viewing the videotapes we saw no overt evidence of crabs trying to get into or onto stations.

The existence of an inhibitory effect of ingesting acetaminophen-containing DNM bait on repeated bait take by nontarget species, either from aversion or due to toxicity or taste, requires further examination. Other than during the beginning of an operational effort, learned aversions to acetaminophencontaining baits might obviate the need for a bait station that excludes nonnative nontargets. There is limited information for determining bait toxicity to coconut crabs; wild-caught crabs that consumed DNM containing two $40 \mathrm{mg}$ acetaminophen tablets were unaffected, presumably, because they avoided eating the tablets (P. Savarie, pers. comm.). No studies have been conducted to determine whether rat species might handle acetaminophen-containing DNM similarly. Wild-caught Fish Crows, however, readily consumed DNM containing acetaminophen tablets but, like crabs, avoided ingesting the tablets (Avery and Tillman 2001). Acute toxicity, measured as the lethal dose, $50 \%$ $\left(\mathrm{LD}_{50}\right)$, of acetaminophen, was $1,994 \mathrm{mg} / \mathrm{kg}$ for Norway rats (Kammer 1987). Assuming the $\mathrm{LD}_{50} \mathrm{~s}$ for roof rats and Polynesian rats are similar to that of Norway rats, comparisons can be made among species based on body mass and the amount of acetaminophen ingested. The standard DNM bait for snake control contains an $80 \mathrm{mg}$ dose of acetaminophen. Using the smallest individual rats from this study to calculate conservative estimates of toxicity, the roof rat would need to consume two acetaminophen-containing DNM to exceed the $\mathrm{LD}_{50}$. The larger Norway rat would require six such baits, but the much smaller Polynesian rat would exceed the lethal dose after consuming just one DNM. Thus, unless rats are like crabs and Fish Crows that eat around acetaminophen tablets in DNM baits, it seems likely that any indi- viduals surviving a first-time ingestion of acetaminophen would soon acquire either an aversion to DNM altogether or learn to avoid ingesting the acetaminophen tablets.

\section{CONCLUSIONS}

On the basis of our results, and considering their relatively high densities on Guam, roof rats are probably the most problematic nontarget species impacting bait stations. The bait station design that would best exclude this species and others is the $\mathrm{C}-\mathrm{O}$ station or the 4 by 12 ; the 2 by 12 station should not be used, and, whenever possible, no stations should be placed on fences, substituting tripods instead. Other foundational work remains to be conducted. First, behavioral studies in the laboratory could easily determine how these rat species handle consumption of acetaminophen-containing DNM and whether the amount of acetaminophen actually consumed causes mortality, an aversion to DNM, or no aversion. Second, field tests on Guam assessing the disposition of roof rats to take DNM from bait stations are needed to determine to what extent the apparent station neophobia we observed is manifest in Guam rats. Such tests would ideally be conducted in an area of known high density for roof rats, using detection methods such as passive integrated transponders, haircollecting devices, or video camera surveillance. Although it seems to be of lesser importance, take by coconut crabs could be evaluated similarly in areas where crabs are abundant and snakes and other nontargets are scarce.

\section{ACKNOWLEDGMENTS}

We are grateful to J. zumBrunnen (Department of Statistics, Colorado State University) for statistical design and analyses. We thank D. Bergman (USDA/APHIS/WS Arizona) and personnel under his supervision for providing roof rats, G. Witmer (USDA/ APHIS/WS/NWRC) for providing Norway rats, and W. Pitt (USDA/APHIS/WS/ NWRC Hilo Station) and personnel under 
his supervision for providing Polynesian rats. We thank M. Defley of Commander Navy Region Marianas on detail to NAVFACMAR for arranging permission to collect coconut crabs on U.S. Navy land and J. Guerrero of USDA Wildlife Services, Guam, for providing the method and assistance in catching crabs. E. Daniels assisted in conducting trials and data collection.

\section{Literature Cited}

Advani, R., and M. Idris. 1982. Neophobic behavior of the house rat Rattus rattus rufescens. Z. Angew. Zool. 69:139-144.

Atkinson, I. A. E. 1985. The spread of commensal species of Rattus to oceanic islands and their effects on island avifaunas. Pages 35-81 in P. J. Moor, ed. Conservation of island birds. ICBP Technical Publication No. 3. Paston, Norwich, United Kingdom.

Avery, M. I., and E. A. Tillman. 2001. Responses of captive fish crows to acetaminophen bait and Brown Treesnake bait stations. Brown Treesnake Research and Management. Andersen Air Force Base, Guam.

Baker, R. H. 1946. A study of rodent populations on Guam, Mariana Islands. Ecol. Monogr. 16:393-408.

Barbehenn, K. R. 1974. Recent invasions of Micronesia by small mammals. Micronesica 10:41-50.

Brooks, J. E., P. J. Savarie, and J. J. Johnson. 1998. The oral and dermal toxicity of selected chemicals to brown tree snakes. Wildl. Res. 25:427-435.

Bull, J. O. 1972. The influence of attractants and repellents on the feeding behaviour of Rattus norvegicus. Pages 154-159 in Proceedings of the 5th Vertebrate Pest Conference. University of California, Davis.

Clapperton, B. K. 2006. A review of the current knowledge of rodent behaviour in relation to control devices. Science for Conservation 263. Department of Conservation, Wellington, New Zealand.

Colvin, B. A., M. W. Fall, L. A. Fitzgerald, and L. L. Loope. 2005. Review of Brown Treesnake problems and control programs:
Report of observations and recommendations. Report to Department of Interior, Office of Insular Affairs, Honolulu, Hawai'i, http://www.invasivespeciesinfo.gov/ animals/controlplans.shtml (accessed 11 March 2009).

Crabb, W. D., and L. O. Emik. 1946. Evaluating rat baits by field acceptance trials on Guam. J. Wildl. Manage. 10:162171.

Daniel, M. J. 1969. A survey of rats on Kapiti Island. N. Z. J. Sci. 12:363-372.

Engeman, R. M., and D. S. Vice. 2001. Objectives and integrated approaches for the control of Brown Treesnakes. Integr. Pest Manage. Rev. 6:59-76.

Gibson-Hill, C. A. 1947. Field notes on the terrestrial crabs. Bull. Raffles Mus. 18:4352.

Grubb, P. 1971. Ecology of terrestrial decapod crustaceans on Aldabra. Philos. Trans. R. Soc. Lond. B Biol. Sci. 260: 411-416.

Howard, W. E. 1987. Rodent-free using permanent bait stations. Pages 147-154 in C. G. J. Richards and T. Y. Ku, eds. Control of mammal pests. Taylor and Francis, London.

Jojola-Elverum, S. M., J. A. Shivik, and L. Clark. 2001. Importance of bacterial decomposition and carrion substrate to foraging brown treesnakes. J. Chem. Ecol. 27:1315-1331.

Kammer, E. 1987. Isoxazole derivatives and medicaments containing these compounds. U.S. Patent Document 4636513.

Key, G., and R. D. Woods. 1996. Spool and line studies on the behavioral ecology of rats (Rattus spp.) in the Galápagos Islands. Can. J. Zool. 74:733-737.

Lindsey, G. D., S. M. Mosher, S. G. Fancy, and T. D. Smucker. 1999. Population structure and movements of introduced rats in an Hawaiian rainforest. Pac. Conserv. Biol. 5:94-102.

Marshall, J. T. 1985. A problem in avian conservation. Wilson Bull. 97:259-262.

McCartney, W. C. 1970. Arboreal behavior of the Polynesian rat (Rattus exulans). BioScience 20:1061-1062.

Moors, P. J., I. A. E. Atkinson, and G. H. 
Sherley. 1992. Reducing the rat threat to island birds. Bird Conserv. Int. 2:93-114.

Mueller-Dombois, D., and F. R. Fosberg. 1998. Vegetation of the tropical Pacific islands. Springer, New York.

Nelson, J. T., B. L. Woodworth, S. G. Fancy, G. D. Lindsey, and E. J. Tweed. 2002. Effectiveness of rodent control and monitoring techniques for a montane rainforest. Wildl. Soc. Bull. 30:82-92.

Pervez, A., S. M. Ahmed, S. Ahmad, and S. W. Ali Rizvi. 1999. The significance of additives to enhance poison bait acceptance against rodents damaging paddy in lower Sindh, Pakistan. Pak. J. Zool. 31:207-210.

Reyne, A. 1939. On the food habits of the coconut crab (Birgus latro), with notes on its distribution. Arch. Neerl. Zool. 3:283-320.

Robins, J. H., M. Hingston, E. MatisooSmith, and H. A. Ross. 2007. Identifying Rattus species using mitochondrial DNA. Mol. Ecol. Notes 7:717-729.

Savarie, P. J., D. L. York, J. C. Hurley, and S. Volz. 2000. Testing the dermal and oral toxicity of selected chemicals to brown treesnakes. Pages 139-145 in T. P. Salmon and A. C. Crabb, eds. Proceedings of the 19th Vertebrate Pest Conference. University of California, Davis.

Savidge, J. A. 1986. The role of disease and predation in the decline of Guam's avi- fauna. Ph.D. diss., University of Illinois, Champaign-Urbana.

- 1987. Extinction of an island forest avifauna by an introduced snake. Ecology 68:660-668.

Spurr, E. B., G. A. Morriss, J. Turner, C. E. O'Connor, and P. Fisher. 2007. Bait station preferences of ship rats. DOC Research and Development Series 271. Department of Conservation, Wellington, New Zealand.

Spurr, E. B., C. E. O'Connor, G. A. Morriss, and J. Turner. 2006. Bait station preferences of Norway rats. DOC Research and Development Series 255. Department of Conservation, Wellington, New Zealand.

Tobin, M. E., A. E. Koehler, and R. T. Sugihara. 1997. Effects of simulated rat damage on yields of macadamia trees. Crop Prot. 16:203-208.

Wiewel, A. S., A. A. Yackel Adams, and G. H. Rodda. 2009. Distribution, density, and biomass of introduced small mammals in the southern Mariana Islands. Pac. Sci. 63:205-222.

Williams, J. M. 1973. The ecology of Rattus exulans (Peale) revisited. Pac. Sci. 27:120127.

Zar, J. H. 1984. Biostatistical analysis. 2nd ed. Prentice-Hall, Englewood Cliffs, New Jersey. 
